\title{
A comparative analysis of the determinants of profitability of commercial and microfinance banks in Nigeria
}

\author{
Ige Olaoluwa Tosin ${ }^{1}$, Adewumi Otonne ${ }^{2}$ \\ Department of Economics, University of Ibadan, Oyo State, Nigeria ${ }^{1}$, \\ Research Associate at the Department of Economics, University of Ibadan, Oyo State, Nigeria ${ }^{2}$ \\ igetosin2015@gmail.com ${ }^{1}$, otonne3@gmail.com ${ }^{2}$
}

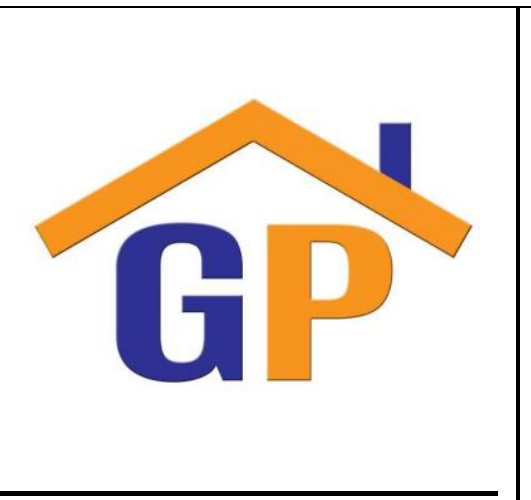

Article History

Received on 23 December 2019

$1^{\text {st }}$ Revision on 31 December 2019

$2^{\text {nd }}$ Revision on 6 January 2020

$3^{\text {rd }}$ Revision on 20 February 2020

$4^{\text {th }}$ Revision on 4 March 2020

$5^{\text {th }}$ Revision on 10 March 2020

Accepted on 10 March 2020

\begin{abstract}
Purpose: The study aims to examine the determinants of profitability of commercial and microfinance banks in Nigeria, in order to be able to highlight the possible effect of Central Bank of Nigeria policy actions in influencing the internal factors and subsequently the profitability of the banks in Nigeria.
\end{abstract}

Research methodology: The study adopted the panel data research design. Out of the total number of 22 commercial banks and 898 microfinance banks the study sampled 4 commercial banks and 4 microfinance banks using random sampling technique, and based on the availability of data. Data were sourced from the annual balance sheets and income statement of banks from 2010 to 2018 and analysed using the Random Effect Panel Estimation Technique.

Finding: Findings from the study show that liquidity ratio is not a strong determinant of banks profitability whether commercial or microfinance banks while capital adequacy is a significant determinants of the profit level in both banks with positive effect for microfinance and negative effect for commercial banks. The study also found that real GDP is a significant determinant of only commercial banks profitability. This by implication indicates that the recent policy action by the central bank which saw the increase of cash reserve ratio from $22.5 \%$ to $27.5 \%$ is expected to have an insignificant reduction on the profitability of the banks.

Limitation:The major limitation of the study is the use of a single measure of profitability and a single measure of external factor. The study period as well as its sample size was also considered as limitation.

Contribution: Findings from this study are useful to the management of the banks, the selected banks to be more specific, and shareholders. Also, this study provides insights on the possible effect of the recent policy of the Central Bank on the banking sector. Thus, the results of this study are useful to policy makers and regulators of the financial system in Nigeria.

Keywords:Profitability, Commercial Bank, Microfinance Banks, Liquidity Ratio, Capital Adequacy, Return on Asset, Real GDP

How to cite: Tosin, I. O., Otonne. A. (2020). A comparative analysis of the determinants of profitability of commercial and microfinance banks in Nigeria. International Journal of Financial Accounting and Management, 1(3), 173-182. 


\section{Introduction}

The major objective of business organizations including banks is profit making (Adeusi, Kolapo \& Aluko, 2014). This objective is the bed rock of other objectives such as shareholder wealth maximization, etc. According to Adeusi, Kolapo \& Aluko (2014) the strength of any bank is tied to its profitability. As a result, the management of banks in Nigeria see profit making as a necessity not only for the firm, but also for the economy at large. The banking system in Nigeria which is a part of the financial sectors consists of different banks such as commercial banks and micro-finance banks, and these banks and the financial sector in general contribute to the economic development of the nation through mobilization of funds into investments, poverty alleviation, etc. (Levine, Loayza, \& Beck, 2000). According to Osuagwu (2014), both at the micro and macro level profitability of banks is an important ingredient for the financial sector development. At the micro level a higher profitability reduces the exposure of the banks to external shocks and fragility while at the macro level a higher profitability generates a strong and formidable financial sector that can facilitate growth and development of the economy.

In an attempt to promote improved balance sheet, improve the capacity to make profit and the stability of the banks in Nigeria, the regulators of the financial system have introduced various policy measures such as increased minimum share capital of both commercial and microfinance banks to reform the financial sector (Aburime, 2008). Unfortunately, it is not clear what the impact of these reforms is on the profitability of the banking sector as studies show mixed effect of these reforms on banks in Nigeria. Moreover, Bhavish, Ayush, Sheereen, \& Hema, (2017) noted that banks are influenced by factors both internal and external. They identified the internal factors to include equity ratio, bank size, deposit size etc while the external factors include gross domestic product, exchange rate, interest rate etc. These factors affect the profitability of the banks, which in turn affect the development of the financial sector and subsequently the growth of the economy. Because of how crucial the profitability of the banks is to the economy, studies have attempted to explore the determinant of the profitability of the banks using different techniques. These studies include Ani, Ugwunta \& Imo (2012), Babalola (2012), Adeusi, Kolapo \& Adewale (2014), and Akani \& Lucky (2015) who examined the determinants of profitability in commercial banks while Katuka \& Mavhunda (2016) examined the determinants of profitability in micro finance banks. They all found various significant factors that influence profitability of the banking sector. However, more studies have examined the case study of commercial banks than microfinance banks which imply that literatures have largely neglected studies on the determinant of the profitability of micro finance banks leaving a dearth in literature be filled.

The motivation for this study hinged on the dearth of literature on the determinants of profitability in Nigeria on one hand and the recent policy action of the Central Bank on Nigeria to increase the liquidity ratio from $22.5 \%$ to $27.5 \%$ on the other hand. It is not clear empirically what the effect of this policy action is on the profitability of the banks. Therefore, in this paper we advance the body of knowledge through the following contributions. First, we examined the determinant of profitability of microfinance bank in Nigeria which has been ignored in literature. Most studies focused on commercial banks, hence the need to also examine microfinance bank in light of how important this institution is to national development so as to widen the scope of knowledge as it concern Nigerian financial system. Secondly, this study examined comparatively the determinants of profitability of both commercial and microfinance bank. This helps to give holistic view of determinant of profitability in the banking system since the commercial and microfinance banks are the largest in the financial system in Nigeria. This further allows for the design of policies that may improve the profitability of the banking industry. Thirdly, we attempt to examine the effect of the policy action of the Central Bank on the profitability of the commercial and microfinance banks.

This paper therefore focuses on the comparative analysis of the determinants of profitability in the banking system of Nigeria using selected commercial and microfinance banks in a panel data analysis. The rest of this study is divided into five chapters. Following this introductory section, section two entails the review of literature, while section three stipulates the research methodology and develop of 
hypotheses. Section four presents the results and discussion. Section five concludes the study with relevant policy implications.

\section{Literature review and hypotheses development}

\subsection{Profitability and profitability determinants}

Profitability is the level to which an organization or business activities generate financial gain. It the company's ability to yield profits or returns on its sales and investment. Researchers often adopt ratio analysis in measuring the performance of companies. Profitability ratios are used to examine the company ability to earn profit during a specific time (Ezejiofor, Nwakoky \& Okoye, 2016). The common profitability ratios used in existing literatures are:

Price earnings ratio $(\mathrm{P} / \mathrm{E})$ is a market-based measure of profitability that assess the share price/Market value of the stockholder's equity by the earnings per share of the company. It is calculated as:

$\mathrm{P} / \mathrm{E}$ ratio $($ Price per share-earnings per share ratio $)=$ Market price per share/Earnings per share

Earnings per share represents the company's ability to generate returns on the stockholders equity in the company. It is the earning proportion of the company shares and can be calculated as:

EPS $($ Earning Per share $)=$ Net profit after tax attributable to shareholders/Outstanding shares

The return on assets (ROA) is the net income for the year divided by the total assets, usually the average value over the year. It is calculated as:

ROE (Return on Equity) $=$ Net profit after tax/shareholders' Equity.

The return on equity (ROE) is an internal measure of profitability in terms of shareholder value, and it is by far the most popular measure of company full profitability. It is calculated as:

ROA $($ Return on asset $)=$ Net Profit after tax/Total asset .

\subsection{Determinants of profitability}

Profitability determinants can be divided into internal and external determinants. The internal determinants are also called company-specific or micro determinants. These determinants are entrenched in the financial statements (that is the balance sheet and income statement) of company making it difficult for company to assess on the surface (Iloska, 2014). Internal determinants include factors such as liquidity, risk management, capital adequacy, operating efficiency, expense management, asset quality and size among others. These factors are under the full control of the company. The external determinants are the factors which are external to the operation of the company but directly or indirectly have significant influence on the performance of the company. They are also called the macroeconomic determinants since the company has no control over such factors. The external factors include money supply, inflation rate, interest rate and gross domestic product (GDP) growth.

\subsection{Empirical review}

In the context of existing studies, empirical studies related to the present study can be broadly classified into two categories: studies that investigate the general determinants of banks' profitability and, the studies that analyse and compare banks with other banks or different organization. In terms of determinants of bank profitability, Ani, Ugwunta \& Imo (2012) studied the determinants of bank profitability in Nigeria using fifteen deposit money banks. The authors delineate the sample banks into banks that were independently standing and banks which retained their brand names after the bank consolidation of 2005. The study used multiple regression technique and found that bank size negatively affect bank profitability significantly. However, asset composition significantly and positively affect bank profitability while only capital adequacy shows positive correlation with profitability. Similarly, Babalola (2012) examined the banks' profitability determinants in Nigeria using bank specific and macroeconomic factors with multiple regression technique. The study found that capital adequacy is the only significant determinant of bank profitability in the short run in Nigeria while bank size and tangibility of the bank are the significant determinants of bank profitability in the long run in Nigeria. 
Adeusi, Kolapo \& Adewale (2014) investigated the factors that influence the commercial banks profitability in Nigeria. The study used pool regression analysis of the ordinary least squared to examine the significance of the factors. The study sampled fourteen banks in fourteen years and measured profitability with return on assets while the examined factors are capital adequacy ratio, asset quality, management efficiency, liquidity ratio, inflation, and economic growth. The study found that the significant determinant of commercial banks' profitability are asset quality, management efficiency, and economic growth using both fixed and random effect models. Also, the study further observed that in all the models, asset quality remains a significant determinant of profitability. Thus, the study concluded that asset quality and credit risk are major determinant of commercial banks' profitability.

Akani \& Lucky (2015) empirically examined the impact of capital adequacy ratio on profitability of commercial banks in Nigeria having observed that capital adequacy has been identified as one of the major determinants of profitability. With the intent of examining the dynamic long run relationship between capital adequacy ratio and profitability, the study used Johansen co-integration techniques in vector error correction model (VECM) and granger causality test. The study measured profitability with Return on Asset (ROA), Return on Investment (ROI) and Return on Equity (ROE) and measured capital adequacy with Adjusted Capital to Risk Asset Ratio (ACRR), Capital to Deposit Ratio (CTD), Capital to Net Loans and Advances Ratio (CNLAR), Capital to Risk Asset Ratio (CRA) and Capital to Total Asset Ratio (CTAR). It found that there is a significant and positive long run dynamic relationship between return on asset on one hand and capital to risk asset ratio and capital to deposit ratio on the other hand. The study observed that other indicators of capital adequacy are negatively correlated with profitability. Lastly, the study established a two-way causality between return on asset and adjusted capital to risk asset ratio as well as between return on asset and capital to net loans and advances ratio.

Katuka \& Mavhunda (2016) examined the profitability determinants of microfinance banks in Zimbabwe. The study used ordinary least squared multiple regression technique and found that return on assets which is the profitability determinant is determined by microeconomic and political variables. Specifically, cost-efficiency ratio, cost-per-borrower ratio and political instability index significantly determine profitability of microfinance banks in Zimbabwe. Conversely, the study showed that debt/equity ratio, branch network growth and write-offs growth are not significant in explaining profitability of the banks. Also, total loan volatility is high for microfinance banks but total asset exhibits upward trends. The study concluded that microfinance banks needs to frequently and closely monitor cost-per-borrower ratio.

In term of comparing the profitability, Boston (2005) after the East Asian financial crisis did a comparative analysis of the profitability of domestic and foreign banks in Thailand with micro level panel data. The study used pooled cross-bank regression method and found that all the banks in the region had improved their performance since the end of the financial crisis. The study major findings shows that foreign banks had performed higher than domestic banks in term of profitability with wide margin. The author concluded that the higher performance of foreign banks to Thailand's banks was a result of the relative effectiveness of the financial restructuring programs of those foreign banks. Muhamad, Mohd \& Edina (2013) examined the effect of bank specific and macroeconomic variables on the profitability performance of Islamic and conventional banks in Malaysia. The study sampled seventeen conventional banks against thirteen Islamic banks over 5 years. Under the pooled ordinary least squared analysis, the study found that profitability determinants are liquidity ratio and macroeconomic variables. Using the random effect model, the study found that liquidity ratio is the sole determinant of profitability. Conversely, using the fixed effect model, the study found macroeconomic variable as well as the type of bank are the main determinant of profitability. Comparatively, the study noted that Islamic banks are profitable than the conventional banks in Malaysia.

Similarly, Muda, Shaharuddin \& Embaya (2013) compared the determinant of the profitability of domestic Islamic bank side by side the foreign Islamic banks in the same Malaysia. The study used generalized least squared (GLS) technique with unbalanced panel data of seventeen Islamic banks. These sampled banks were divided into domestic and foreign banks. The study found that profitability determinants differs across domestic and foreign Islamic banks. It established that loans, overhead expenses, efficiency, growth rate of gross domestic product and bank size are the major determinants 
of the domestic banks' profitability in Malaysia while GDP per capita is the only significant determinant of foreign banks' profitability. However, banks deposits, capital reserves, inflation and banks' age are significant profitability determinants of both domestic and foreign banks in Malaysia. Furthermore, the study found that foreign Islamic banks are less profitable than domestic Islamic banks. The study concluded that global financial crisis affects domestic Islamic banks' profitability but not foreign Islamic banks' profitability.

Alnaa, Adongo \& Juabin (2016) observed that Financial Sector Adjustment Programme implementation has ushered in a significant number of foreign banks into Ghana. This in flocks has created intense competition within the banking sector in the country. Thus, the study sought to compare the profitability of foreign and domestic banks performance in Ghana using three domestic banks and three foreign banks. In order to properly capture the profitability of these banks, the study used Return on Assets (ROA), Capital Adequacy (CA), Return on Equity (ROE) and Management Efficiency (ME) as measures of banks' profitability. The study found that foreign banks have performed better than domestic banks in terms of return on assets, capital adequacy, and return on equity while local/domestic banks have performed better than foreign banks in almost all the period under study only in terms of management efficiency. Therefore, the study concluded that foreign banks have outperformed local banks during the period under study in Ghana. Similarly, Ezejiofor, Nwokoby \& Okoye (2016) comparatively evaluate the investment decision of manufacturing firm and commercial banks in Nigeria. The study used ex-post facto and time series research design and analysed the data with financial ratio and t-test statistics. Particularly, the study assessed the debt-equity ratios, dividend coverage ratio and profitability ratio of commercial banks and manufacturing firms so as to determine if they are significantly different from one another. The study found that commercial bank profitability is significantly different from the profitability of manufacturing firm. Also, the study observed that there are significant difference between the debt-equity ratio and dividend coverage ratio of commercial banks and manufacturing firms. The study concluded that the more the solvency of an organization, the less its profitability and manufacturing firms have more return on investment comparatively to commercial banks. Thus, no known study have examined the comparative performance of commercial and microfinance banks locally and elsewhere. Due to the dearth of studies on the subject matter, this study sought to examine the broad hypothesis of no significant difference in the profitability of commercial and microfinance banks in Nigeria.

Hence, this study aims to provide answers to the following research hypotheses.

$$
\begin{gathered}
H_{0}^{1} \text { : Liquidity ratio is not a significant determinant of bank profitability } \\
H_{0}^{2} \text { : Capital adequacy ratio is not a significant determinant of bank profitability } \\
H_{0}^{3} \text { : Real gross domestic product is not a significant determiant of bank profitability }
\end{gathered}
$$

\section{Research methodology}

Due to the nature of the data set, the study employed a secondary data. Variables used in the study are derived from a simplified CAMEL model (the five components of a bank's condition model: Capital adequacy, asset quality, management, earning and liquidity) to capture the internal determinants and macroeconomic variables as the external determinant. Thus, the data series are sourced from the financial statement of the selected banks and the central bank statistical bulletin (2018). The study employed a panel data analysis ranging from 2010 to 2018. Table 1 presents the selected banks for the study. These banks are selected from a population of 22 commercial banks and 898 microfinance banks based on availability of data and bank size.

Following Sufian, Kamaruin \& Noor (2012) the regression model for the study is written as follows:

Where:

$$
R O A=\alpha_{0}+\alpha_{1} L Q R+\alpha_{2} C A R_{L P G}+\alpha_{3} R G D P+\varepsilon
$$

ROA $=$ Return on Asset a measurement of profitability.

LIQ = Liquidity ratio measures the internal factors

$\mathrm{CAR}=$ Capital Adequacy ratio measures the internal factors 
RGDP $=$ Real GDP measures the external factors

$\alpha_{0}$ is the intercept, $\alpha_{i}$ is regression coefficient and $\varepsilon$ is an error term.

The profitability variable presented in this study is return on assets (ROA). This ratio measures the bank's ability to generate profits from the bank's assets. This is computed by dividing the net profits with total assets. That is; $R O A=\frac{\text { Net Profit }}{\text { Total Asset }}$

The internal variables of the study include two ratios: Liquidity ratio and Capital adequacy ratio. Liquidity ratio is characterized by the ratio of total loans to total assets. That is; $Q R=\frac{\text { Total Loans }}{\text { Total Asset }}$.

Higher liquidity ratio means less liquidity possessed by the banks and hence increases the expected return and profitability.

Capital adequacy ratio is measured by taking the ratio of total equity over total assets. That is; $C A R=$ $\frac{\text { Total equity }}{\text { Total Asset }}$

Banks which possess high capital ratio tend to be more profitable, much safer in the case of liquidation and also require less external funding. Thus, capital adequacy ratio positively influences profitability. Also, in order to isolate the effect of bank's features on profitability, real GDP as an indicator of macroeconomic feature is included in the model as an external determinant.

Table 1: Selected Sample of Commercial Banks and microfinance banks.

\begin{tabular}{|l|l|l|}
\hline S/N & Commercial Banks & Microfinance Banks \\
\hline 1. & Access Bank plc. & Accion Microfinance Bank \\
\hline 2. & First Bank plc. & Lapo Microfinance Bank \\
\hline 3. & GTBank plc. & Fortis Microfinance Bank \\
\hline 4. & Zenith Bank plc. & Umuchinemere Microfinance Bank \\
\hline
\end{tabular}

\section{Results and discussions}

\subsection{Descriptive statistics}

Summary of the descriptive statistics (on Nigeria banks' return on asset, liquidity ratio, capital adequacy ratio, and real GDP) shows that there seems to be no evidence of significant variations within the mean, median, maximum and minimum of each data set for both commercial banks and microfinance banks. Comparatively, microfinance banks seem to have higher mean, median, minimum and maximum value than commercial banks except for liquidity ratio where commercial banks were found to be more liquid than the microfinance.

The standard deviation and sum of squared deviation enable the discovery of the most volatile variable. From the table, the study observes that banks' liquidity ratio and RGDP have the highest standard deviation as well as highest sum of squared deviation and are therefore the most volatile of all the variables. Similarly, table 2 show that all the variables (except banks' return on asset and microfinance banks' liquidity ratio) are normally distributed since their probabilities computed for the Jacque-Bera Chi-square distribution are significantly different from zero (probabilities are less than 0.05).

Table 2: Descriptive statistics of commercial and microfinance banks profitability and its determinants

\begin{tabular}{|c|c|c|c|c|c|c|c|}
\hline & \multicolumn{3}{|c|}{ Commercial Banks } & \multicolumn{3}{|c|}{ Microfinance Banks } & Economy \\
\hline & ROA & LIQ & CAR & ROA_M & LIQ_M & CAR_M & RGDP \\
\hline Mean & 0.025926 & 5.274835 & 0.313964 & 0.055115 & 4.400639 & 0.280429 & 5.126581 \\
\hline Median & 0.025548 & 6.201688 & 0.165083 & 0.062419 & 4.465369 & 0.225610 & 5.050971 \\
\hline $\begin{array}{l}\text { Maximu } \\
\mathrm{m}\end{array}$ & 0.050318 & 7.708480 & 0.891902 & 0.122400 & 8.985559 & 0.645047 & 9.539786 \\
\hline
\end{tabular}




\begin{tabular}{|l|l|l|l|l|l|l|l|}
\hline $\begin{array}{l}\text { Minimu } \\
\mathrm{m}\end{array}$ & 0.001100 & 1.121200 & 0.125135 & 0.001336 & 1.550275 & 0.111290 & 2.786398 \\
\hline $\begin{array}{l}\text { Std. } \\
\text { Dev. }\end{array}$ & 0.010402 & 2.356530 & 0.294667 & 0.029767 & 1.898378 & 0.150676 & 1.885532 \\
\hline $\begin{array}{l}\text { Skewne } \\
\text { ss }\end{array}$ & -0.029749 & -0.989227 & 1.320090 & 0.165787 & 0.370805 & 1.242023 & 1.166450 \\
\hline Kurtosis & 3.064568 & 2.367136 & 2.781776 & 2.206353 & 2.578494 & 3.573923 & 3.911101 \\
\hline $\begin{array}{l}\text { Jarque- } \\
\text { Bera }\end{array}$ & 0.011564 & 6.472200 & 10.52726 & 1.109725 & 1.091480 & 9.749802 & 9.408790 \\
\hline $\begin{array}{l}\text { Probabil } \\
\text { ity }\end{array}$ & 0.994235 & 0.039317 & 0.005176 & 0.574151 & 0.579413 & 0.007636 & 0.009055 \\
\hline Sum & 0.933339 & 189.8941 & 11.30269 & 1.984124 & 158.4230 & 10.09545 & 184.5569 \\
\hline $\begin{array}{l}\text { Sum Sq. } \\
\text { Dev. }\end{array}$ & 0.003787 & 194.3632 & 3.039003 & 0.031013 & 126.1344 & 0.794612 & 124.4331 \\
\hline $\begin{array}{l}\text { Observa } \\
\text { tions }\end{array}$ & 36 & 36 & 36 & 36 & 36 & 36 & 36 \\
\hline
\end{tabular}

Source: Authors computation (2020)

\subsection{Unit Root Test results}

The results of the unit root test are shown in Table 3. Since it is possible for the banks in consideration to be homogeneous, it is essential that the data series be subjected to unit root test. The study employs the Fisher's Panel ADF and Philip Perron (PP) tests. The panel unit-root test was applied to check whether the variables in the model are stationary or non-stationary. Findings show that most of the series are stationary at levels using Fisher's Panel ADF test at 10\% level of significance except for microfinance banks' liquidity ratio and RGDP. However, using Fishers PP test, RGDP and microfinance banks' liquidity ratio are stationary at levels with intercept \& trend at $1 \%$ level of significance. These findings show that the series are stationary at levels as revealed by the tests.

Table 3: Summary of Panel Unit Root Test

\begin{tabular}{|l|l|l|l|l|l|}
\hline \multicolumn{3}{|l|}{ Intercept } & \multicolumn{2}{l|}{ Intercept \& Trends } & \\
\hline Variables & $\begin{array}{l}\text { ADF-Fisher } \\
\text { Chi-square }\end{array}$ & $\begin{array}{l}\text { PP-Fisher Chi- } \\
\text { square }\end{array}$ & $\begin{array}{l}\text { ADF-Fisher } \\
\text { Chi-square }\end{array}$ & $\begin{array}{l}\text { PP-Fisher Chi- } \\
\text { square }\end{array}$ & $\begin{array}{l}\text { Order of } \\
\text { Integration }\end{array}$ \\
\hline ROA & 11.4161 & $14.0951^{* * *}$ & $43.9346^{*}$ & $33.2977^{*}$ & $\mathrm{I}(0)$ \\
\hline LIQ & $22.0871^{*}$ & $40.9681^{*}$ & $38.0288^{*}$ & $47.8591^{*}$ & $\mathrm{I}(0)$ \\
\hline CAR & $23.5846^{*}$ & $39.7488^{*}$ & $38.0697^{*}$ & $47.2556^{*}$ & $\mathrm{I}(0)$ \\
\hline ROA_M & $25.1000^{*}$ & 11.7310 & $31.2642^{*}$ & 9.01319 & $\mathrm{I}(0)$ \\
\hline LQI_M & 12.3797 & 4.53942 & $22.2068^{*}$ & 13.3271 & $\mathrm{I}(0)$ \\
\hline CAR_M & $13.9628^{* * *}$ & 4.89783 & $21.5611^{*}$ & 8.84847 & $\mathrm{I}(0)$ \\
\hline RGDP & 11.8269 & $37.2358^{*}$ & 10.7519 & $16.5470^{* *}$ & $\mathrm{I}(0)$ \\
\hline
\end{tabular}

Source: Authors Computation (2020)

Note: $* * *, * *, *$ imply signififcance at $1 \%, 5 \%$ and $10 \%$ respectively.

\subsection{Hausman Test Result}

To determine the most appropriate model for the study, the Hausman Test is employed. The Hausman specification test compares the estimates of the fixed and random estimators; with a null hypothesis of random effect model and an alternative hypothesis of fixed effect, the test help to decide the appropriate model to use for the study. The result of the test is presented in Table 4. The result shows that the null hypothesis of no individual effects (Random effect) was tested against the alternative hypothesis of the presence of individual effect (fixed effect). With the p-value of the test statistics less than 0.05 , the null hypothesis is not rejected at $5 \%$ level of significance. This indicates that the sampled banks are nearly 
homogeneous; as a result the bank-specific differences need not be controlled for. This informed the use of random effect model in this study.

Table 4: Correlated Random Effect Hausman Test

\begin{tabular}{|c|c|c|c|c|}
\hline \multicolumn{2}{|c|}{ Test Summary } & Chi-Sq. Statistic & Chi-Sq. d.f. & Prob. \\
\hline \multicolumn{2}{|c|}{ Cross-section and period random } & 907.890146 & 3 & 0.0000 \\
\hline \multicolumn{5}{|c|}{ Cross-section random effects test comparisons: } \\
\hline Variable & Fixed & Random & $\operatorname{Var}($ Diff.) & Prob. \\
\hline LQI & -0.003639 & -0.004781 & -0.000001 & - \\
\hline CAR & -0.037964 & -0.048086 & 0.000094 & 0.2973 \\
\hline RGDP & -0.002636 & -0.002848 & -0.000000 & - \\
\hline
\end{tabular}

\subsection{Random Effect Panel Model Results}

Having established the suitability of the random effect model for the banks, the results presented in Table 5. The results show that liquidity ratio is a negative and insignificant determinant of commercial banks profitability. Similarly, liquidity ratio is an insignificant determinant of microfinance banks' profitability. However, Capital adequacy was found to be a significant but negative determinant of commercial banks profitability. Conversely, capital adequacy is a positive and significant determinant of microfinance bank profitability. Also, the economy's RGDP is a significant but negative determinant of commercial banks profitability. However, it was found to be an insignificant determinant of microfinance banks' profit level. This means that capital adequacy ratio and RGDP are the only significant determinants of commercial banks profitability while only capital adequacy stands as the significant determinants of microfinance banks profitability. Overall, the F-tests show that in both models, the estimated parameters of the independent variables are stable in predicting the dependent variable. That is, the liquidity ratio, capital adequacy ratio and real gross domestic products are jointly significant determinants of profitability ratio. This implies that these variables working together determine the profit level of the banks. Also, the value of the Durbin Watson (DW) test statistics indicates that there is no evidence of autocorrelation problem in both the commercial bank and microfinance banks' models.

More specifically, findings from the study show that the bank's ability to repay short-term creditors out of its total cash captured by the liquidity ratio does not determine both the commercial and microfinance banks profit level. This is consistent with the findings of Adeusi, Kolapo \& Adewale (2014) but in contrast to Muhamad, Mohd \& Edina (2013) who found that liquidity ratio is a significant determinant of profitability. In agreement with Babalola (2012) short run dynamism, the study also suggests that the financial strength of banks or financial institutions which measures their capital adequacy has important role in the determination of commercial banks profit level. However, the more adequate the capital of these commercial banks are, the lesser these banks are able to generate more profits. This implies that the banks lack the capacity to transform their capital base into useful activities that yield profits. Conversely, the microfinance banks have been able to strategically transform the financial strength of their bank into useful activities that induce the growth of the profit level.

The influence of the external business environment on the banking operation captured by the real GDP is significant on the commercial bank but insignificant on the microfinance banks. Growth of the real sector of the economy have undesirable effect on the commercial banks which could be the product of the instability in the Nigerian business environment which is characterised by fluctuation inflation rate, violence and terrorism, unstable fuel price, unreliable data estimates among others. Microfinance banks possibly due to their small nature have not felt the influence of the general business environment growth in the country. This finding is consistent with Muda, Shaharuddin \& Embaya (2013) who found real GDP and its growth rate as significant determinant of both domestic and foreign banks' profitability. 
Table 5: Regression Estimates: Random Effect Model

\begin{tabular}{|l|l|l|l|l|}
\hline \multirow{2}{*}{$\begin{array}{l}\text { Independent } \\
\text { Variables }\end{array}$} & Commercial Banks & \multicolumn{2}{l|}{ Microfinance Banks } \\
\cline { 2 - 5 } & Coefficients & Prob. & Coefficients & Prob. \\
\hline C & $0.080846^{*}$ & 0.0035 & 0.033392 & 0.3127 \\
\hline LQI & -0.004781 & 0.1058 & -0.001396 & 0.6995 \\
\hline CAR & $-0.048086^{* *}$ & 0.0521 & $0.074264^{* *}$ & 0.0961 \\
\hline RGDP & $-0.002848^{* *}$ & 0.0133 & 0.001373 & 0.2690 \\
\hline R2 & 0.217001 & - & 0.201953 & - \\
\hline F-Test & $2.956166^{* *}$ & 0.047137 & $2.699289^{*}$ & 0.062146 \\
\hline DW & 1.291703 & - & 1.608871 & - \\
\hline
\end{tabular}

\subsection{Diagnostic Test}

To ensure validity of the findings and examine if cross sectional dependency exists in the empirical results, cross sectional dependency diagnostic test was conducted. Employing Breusch-Pagan LM, Pesaran scaled LM and Pesaran CD tests to check for possible cross dependency in the estimated results. The results of the tests show that the estimates of the random effect model are free from cross sectional dependency since the p-values of the test are greater than 0.05 which indicates that the null hypothesis of no cross-sectional dependency is rejected for both the commercial and microfinance banks. This is presented in table Table 7.

Table 7: Diagnostic Test Results

\begin{tabular}{|l|l|l|l|l|l|l|}
\hline \multicolumn{4}{|l|}{ Commercial Banks } & \multicolumn{4}{l|}{ Microfinance Banks } \\
\hline Test & Statistics & df & Prob & Statistics & df & Prob \\
\hline Breusch-Pagan LM & 9.878326 & 6 & 0.1299 & 6.536052 & 6 & 0.3659 \\
\hline Pesaran scaled LM & -0.035124 & & 0.9720 & -0.999956 & & 0.3173 \\
\hline Pesaran CD & -2.209280 & & 0.0272 & 1.271507 & & 0.2035 \\
\hline
\end{tabular}

\section{Conclusion and policy implication}

Findings from the study provide insight on the determinants of profitability in Nigeria and the effect of the policy actions of the regulator of the financial system in Nigeria. With the increase in the cash reserve ratio by the Central Bank of Nigeria from $22.5 \%$ to $27.5 \%$, and drawing from the findings of the study we expect an insignificant reduction in the profit of the banks (commercial and microfinance) in the financial sector in the short term. By implication the findings of the study also show that for an effective control of the profitability of the financial institutions policy actions that influence the capital adequacy ratio such as the promotion of merger and acquisition, restructuring etc would be relatively more effective. Therefore, both commercial and microfinance bank managements and the regulatory authority should pursue policies that will enhance their capital adequacy.

\section{References}

Aburime, T. (2008). Determinants of bank profitability: Company-level evidence from Nigeria. Available at SSRN 1106825.

Adeusi, S. O., Kolapo, F. T. \&Adewale, A. O. (2014). Determinants of commercial banks' profitability: Panel evidence from Nigeria. International Journal of Economics, Commerce and Management, 11(12), 1-18.

Akanni, H. W. \& Lucky, L. A. (2015). Econometrics analysis of capital adequacy ratios and the impact on profitability of commercial banks in Nigeria. Journal of Economics and Finance, 6(6), 1124. 
Alnaa, S. E., Adongo, J. \&Juabin, M. (2016). Comparative analysis of profitability of local and foreign banks in Ghana. Asian Economic and Financial Review, 6(5), 238-246.

Ani, W.U., Ugwunta, O.D. \& Imo, G.I. (2012). Determinants of banking industry profitability in Nigeria: A bank-specific and macroeconomic characteristics analysis. Elixir Finance, 45, 77147719.

Asteriou, D. \& Hall, S. (2007). Applied Econometrics. 3rd ed.New York, NY: Palgrave Macmillan.

Athanasoglou, P.P., Brissimis, S.N. \& Delis, M.D. (2008). Bank-specific, industry-specific and macroeconomic determinants of bank profitability. Journal of International Financial Markets, Institutions and Money, 18(2), 121-136.

Babalola, Y.A. (2012). The Determinants of Banks' Profitability in Nigeria. Journal of Money, Investment and Banking, 10(24), 6-16.

Bhavish, J., Ayush, R., Sheereen, F., \& Hema, S. (2017). What determines the profitability of nonbank deposit taking institutions?: some evidence from Mauritius. The Journal of Developing Areas, 51(4), 239-253.

Bobakova, I. V. (2003). Raising the profitability of commercial banks. BIATEC, 11, 21-25.

Boston, S.(2005). Comparative study of domestic and foreign bank performance in Thailand: The regression analysis. Journal of Business and Economics, 38(1), 63-68.

Central Bank of Nigeria (2005). Microfinance Policy, Regulatory and Supervisory Framework for Nigeria. CBN Publication, Abuja.

Ekezie, E. S. (1997). Money, Financial Institutions and Markets. Onitsha: Africana-FepPublishers.

Ezejiofor, R., Nwokoby, N. P. \& Okoye, J. F. (2016). Comparative analysis of the investment decision of selected manufacturing firms and commercial banks in Nigeria. International Journal in Management and Social Science, 4(8), 193- 218.

Famakinwa, S., Oduniyi, M., Aminu, A., Obike, U \&Ugwu, E. (2004). Shape of Banks to Come (2): The Soludo Solution. This day, July 12, 10(3367).

Gujarati, D. N. \& Porter, D. C. (2009). Basic Econometrics. 5th ed. Boston, Mass: McGraw-Hill.

Iloska N. (2014). An analysis of banks profitability in Macedonia. Journal of applied Economics and Business, 2(1), 31-50.

Katuka, B. \& Mavhunda, R. (2016). Profitability determinants in microfinance industry: Case of Zimbabwe (2010-2014). Journal of Global Economy, 12(4), 219-241.

Levine, R., Loayza, N., \& Beck, T. (2000). Financial intermediation and growth: Causality and causes. Journal of monetary Economics, 46(1), 31-77.

Muda, M., Shaharuddin, A. \& Embaya, A. (2013). Comparative analysis of profitability determinants of domestic and foreign Islamic banks in Malaysia. International Journal of Economics and Financial Issues, 3(3), 559-569.

Muhamad, A., Mohd, A. O. \& Edina, M. (2013). Profitability determinants of Islamic and conventional banks in Malaysia: A panel regression approach. Terengganu International Finance and Economics Journal, 3(1), 1-7.

Osuagwu, E. (2014). Determinants of bank profitability in Nigeria. International Journal of Economics and Finance, 6(12).

Sufian, F., Kamarudin, F., \& Noor, N. (2012). Determinants of revenue efficiency in the Malaysian Islamic banking sector. Journal of King Abdulaziz University, 25(2), 195-224.

Yakubu M.U. (2008). The impact of oil on Nigeria economy: The boom and bust cycles. $C B N$ Bulletin, 32(2). 